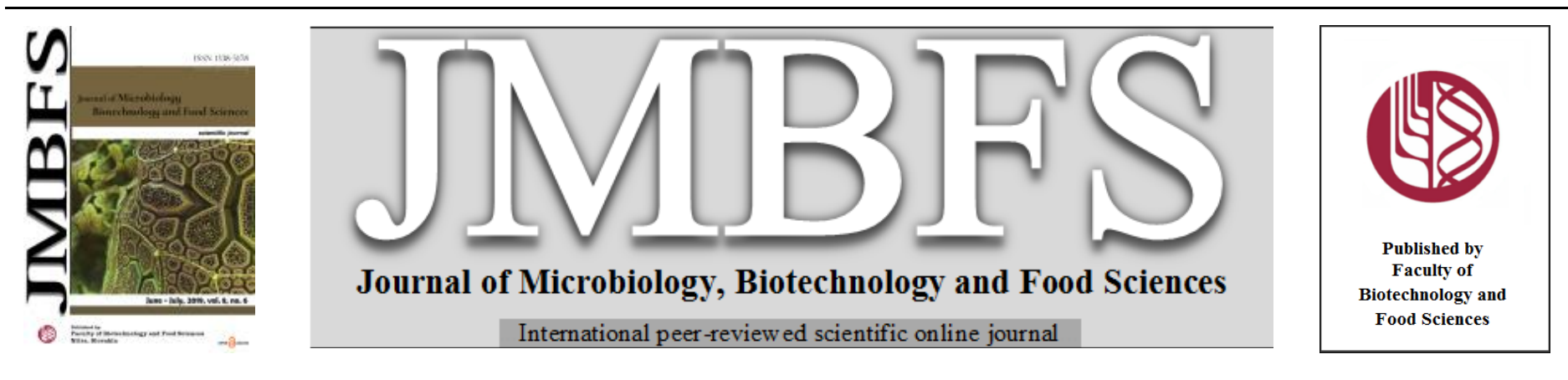

\title{
POLYPHENOL-RICH POMEGRANATE EXTRACT AS A POTENTIAL MODULATOR OF STEROIDOGENESIS IN HUMAN OVARIAN CELLS
}

\author{
Simona Baldovskál, Katarína Michalcovál, Marek Halenár ${ }^{1}$, Angel A. Carbonell-Barrachina², Adriana Kolesárová*l
}

Address(es): prof. MSc. Adriana Kolesárová, $\mathrm{PhD}$.,

${ }^{1}$ Slovak University of Agriculture in Nitra, Faculty of Biotechnology and Food Sciences, Department of Animal Physiology, Tr. A. Hlinku 2, 94976 Nitra, Slovak Republic, phone number: +421-37-641 4119

${ }^{2}$ University of Miguel Hernández, Faculty of Experimental Sciences, Department of Agro-Food Technology, Crta. de Beniel, Km. 3,2, 03312, Orihuela (Alicante), Spain.

*Corresponding author: adriana.kolesarova@uniag.sk

doi: 10.15414/jmbfs.2019.8.6.1343-1346

\section{ARTICLE INFO}

Received 7. 1. 2019

Revised 6. 2. 2019

Accepted 21. 2. 2019

Published 1. 6. 2019

Regular article

open $\bigodot_{\text {access }}$

\begin{abstract}
Pomegranate represents a rich source of phytocompounds with high medicinal value. Nowadays, many studies have shown that the pomegranate extract also possesses anti-oxidant, anti-inflammatory and anti-proliferative effects on cancer cells, thus leading to increased popularity as a functional food and nutraceuticals. The aim of the study was to determine the biological effect of dry pomegranate extract (at concentrations 5, 10, 20 and $40 \mu \mathrm{g} / \mathrm{ml}$; for $24 \mathrm{~h}$ ) on the viability of ovarian cells and the secretion of steroid hormones. Cultures of human ovarian granulosa cells (HGL5) and human ovarian carcinoma cells (OVCAR-3) were used such as a model cell system. The metabolic activity was evaluated by AlamarBlue ${ }^{\mathrm{TM}}$ assay, the release of steroid hormones was assayed by the ELISA method. Experimental results indicated a significant $(\mathrm{P} \leq 0.001)$ increase of proliferation in HGL5 cells after the addition of the extract at the concentrations 5,10 and $20 \mu \mathrm{g} / \mathrm{ml}$. Moreover, the number of viable OVCAR-3 cells significantly $(\mathrm{P} \leq 0.05$; $\mathrm{P} \leq 0.01$; $\mathrm{P} \leq 0.001)$ decreased after the addition of the extract at the concentrations 10, 20 and $40 \mu \mathrm{g} / \mathrm{ml}$ compared to the control. In addition, the secretion of $17 \beta$-estradiol by the HGL5 cells was significantly $(\mathrm{P} \leq 0.05 ; \mathrm{P} \leq 0.001)$ increased at all used concentrations of the extract. Despite to increasing of the 17 -estradiol secretion, progesterone levels produced by the HGL5 cells were not significantly $(\mathrm{P} \geq 0.05)$ affected at all used concentrations of the extract. The current study provided experimental evidence that the pomegranate extract might be a promising candidate as a potential modulator of steroidogenesis and as a potential chemoprotective agent.
\end{abstract}

Keywords: pomegranate, ovarian cells, steroid hormones, cancer

\section{INTRODUCTION}

Punica granatum L., commonly known as pomegranate, is a deciduous shrub, native to the Mediterranean region (Al-Said et al., 2009). Nowadays, pomegranate has received attention as a functional food and can be used for dietary supplement or nutraceutical and consumed as such as fresh fruit or in processed juice, jam, wine, and powdered capsules that contain extracts of different pomegranate tissues (Aqil et al., 2012; Akhtar et al., 2015)

Many investigators have reported a free radical scavenging and strong antioxidant properties of pomegranate polyphenols including flavonoids, flavonols, and anthocyanins (Elfalleh et al., 2011). The flavonoids such as luteolin, resveratrol, and quercetin are found in the peel pomegranate extract (Choi et al., 2006; Viuda-Martos et al., 2010). Additionally, pomegranates contain hydrolysable tannins, especially ellagitannins such as punicalagin, punicalin, gallotannin (Gil et al., 2000; Landete et al., 2011), condensed tannins, proancyanidins, anthocyanins (Zhang et al., 2011), organic and phenolic acids, including ellagic and gallic acid (Mousavinejad et al., 2009), sterols, triterpenoids, fatty acids, triglycerides, and alkaloids (Seeram et al., 2005). Various parts of the pomegranate fruit have been shown to exert multiple beneficial effects on human health. Clinical and preclinical studies have determined that pomegranates have anti-oxidant (Singh et al., 2014; Zhang et al., 2011), anti-inflammatory (Gonzalez-Trujano et al., 2015), anti-bacterial (Viladomiu et al., 2013), anti-cancer (Syed et al., 2013; Sharma et al., 2017), anti-obesity (Al-Muammar et al., 2012), and neuroprotective (Yuan et al., 2016) activities.

Some plants, including Punica granatum L., contain phytoestrogens. Punic acid, kaempferol and $\beta$-sitosterol present in pomegranate have shown phytoestrogenic activity (Choi $\boldsymbol{e t}$ al., 2006). Phytoestrogens are structurally similar to steroid hormone $17 \beta$-estradiol and compete with the endogenous hormone for binding to estrogen receptor, thus reducing the hormonal effect of endogenous estrogens (Papoutsi et al., 2005).

The ovaries are responsible for the production of sex steroids, various growth factors, transcription factors and cytokines (Kolesarova et al., 2015). The steroid hormones are the best-known and best-characterized secretory products of the ovary (Schams and Berischa, 2002). The influence of steroid hormones, including $17 \beta$-estradiol, progesterone, and others on ovarian functions and female fertility is complex and still requires elucidation. Understanding the mechanisms which regulate ovarian steroidogenesis at the molecular and cellular level requires readily available cells for in vitro studies (Havelock, 2004). The Immortalized human granulosa cell line HGL5 has been previously described in detail (Rainey et al., 1994). The HGL5 cell line exhibits qualities consistent with primary ovarian granulosa cells, includes the ability to produce progesterone and $17 \beta$-estradiol, and offer an optimal tumor-like system for studies focused on gonadotropin-dependent proliferation, cell survival and apoptosis (Patel $\boldsymbol{e t}$ al., 2009). Human ovarian epithelial carcinoma cell line, NIH: OVCAR-3 is an appropriate model system in which to study drug resistance in ovarian cancer, the presence of hormone receptors and has been previously described in detail (Hamilton et al., 1983). Therefore, selected ovarian cell lines HGL5 and OVCAR-3 can serve as useful models for studying signalling pathways and regulation of steroid biosynthesis.

In this in vitro study, the effect of dry pomegranate extract on human ovarian cells, using HGL5 and OVCAR-3 cells was investigated. The objective was to examine the viability of human ovarian cells and the secretion of selected steroid hormones after the addition a number of the pomegranate extract concentrations $(5,10,20$ and $40 \mu \mathrm{g} / \mathrm{ml})$.

\section{MATERIAL AND METHODS}

Cell lines

The human ovarian granulosa cell line HGL5 $(\mathrm{ABM} \otimes, \mathrm{BC}$, Canada) were cultured in Dulbecco's modification of Eagle medium (Sigma-Aldrich, MO, USA), supplemented with $10 \%$ fetal bovine serum (Sigma-Aldrich, MO, USA), $1 \%$ antibiotics/antimycotics (Invitrogen, CA, USA), and incubated in a $5 \% \mathrm{CO}_{2}$ incubator at $37^{\circ} \mathrm{C}$ until $80-90 \%$ confluent. The cells were grown in a standard T75 cell culture flask (Corning Life Sciences, NY, USA) to 80-90 \% confluence. 
The human ovarian carcinoma cell line, NIH: OVCAR-3 was obtained from the American Type Culture Collection (ATCC $®$, VA, USA). The cells were cultured in culture medium RPMI1640 (Gibco-BRL, MD, USA) supplemented with $10 \%$ fetal bovine serum (Sigma-Aldrich, MO, USA), $1 \%$ antibiotics/antimycotics (Invitrogen, CA, USA), $1 \%$ non-essential amino acids (Sigma Aldrich, UK), and incubated in a $5 \% \mathrm{CO}_{2}$ incubator at $37{ }^{\circ} \mathrm{C}$. The cells were grown in a standard T75 cell culture flask (Corning Life Sciences, NY, USA) to 80-90 \% confluence.

\section{Pomegranate extract treatment}

Pomegranate extract used in this study get from commercially purchased capsules from Spain, which contain dry extract of Punica granatum. Total polyphenols in the pomegranate powder present not than less $50 \%$ and punicalagins ( $\alpha$ and $\beta$ ) present even $30 \%$ of the content. Prior to the experiments, pomegranate extract powder was dissolved in culture medium and diluted to the desired concentrations. Depending on the pomegranate extract treatment, the cells were cultured in plates without (control group) or with pomegranate extract at concentrations $5,10,20$ and $40 \mu \mathrm{g} / \mathrm{mL}$ for $24 \mathrm{~h}$.

\section{Cell viability assay}

Cell viability was evaluated using AlamarBlue ${ }^{\mathrm{TM}}$ (BioSource International, Nivelles, Belgium) assay as a suitable indicator of cellular health and viability (Bannerman et al., 2001). Briefly, the HGL5 and OVCAR-3 cells were cultured in a 96-well plate (Grainer, Germany) per $100 \mu \mathrm{L}$ at the density of $1.5 \times 10^{4}$ cells per well and grown overnight in a $5 \%$ $\mathrm{CO}_{2}$ incubator at $37{ }^{\circ} \mathrm{C}$. After pre-incubation, the cells were grown in culture for 24 hours without (control group) or with pomegranate extract $(5,10,20$ and 40 $\mu \mathrm{g} / \mathrm{mL}$ ). The AlamarBlue solution was added to each well 4 hours before the endpoint at a volume of $10 \mu \mathrm{L}$. The AlamarBlue reduction as a result of multiple metabolic reactions was measured spectrophotometrically by recording the absorbance at $560 \mathrm{~nm}$ and $590 \mathrm{~nm}$ using an ELISA microplate reader (Multiskan FC, ThermoFisher Scientific, Finland). For each experiment, wells containing only the AlamarBlue solution without cells were also prepared and incubated. The fluorescence measured in those was used as a background and subtracted. The results were expressed as the percentage of viable cells. Analyses were performed in three independent experiments with replicates per experiment.

\section{ELISA (enzyme-linked immunosorbent assay)}

Concentrations of secreted steroid hormones after supplementation by pomegranate extract were determined using ELISA kit (NOVATEC, Dietzenbach, Germany) according to the manufacturer's instructions. Cells HGL5 were re-seeded in a 24-well culture plate (Grainer, Germany) at a density of $1 \times 10^{5}$ cells per well and incubated in DMEM culture media (control) or with pomegranate extract (at concentrations 5, 10, 20 and $40 \mu \mathrm{g} / \mathrm{mL}$ ) for $24 \mathrm{~h}$. The release of $17 \beta$-estradiol and progesterone was measured spectrophotometrically according to the manufacturer's instructions at a wavelength $450 \mathrm{~nm}$ on an ELISA microplate reader (Thermo Scientific Multiskan FC, Vantaa, Finland) Intra-and inter-assay coefficient for $17 \beta$-estradiol was set at $\leq 9 \%$ and $\leq 10 \%$, for progesterone was set as $\leq 4 \%$ and $\leq 9.3 \%$. The sensitiveness was $8.68 \mathrm{pg} / \mathrm{mL}$ for $17 \beta$-estradiol and $0.05 \mathrm{ng} / \mathrm{mL}$ for progesterone. The results were averaged over 3 different independent experiments with replicates per experiment.

\section{Statistical analysis}

All data were expressed as the mean \pm standard error of the mean (SEM) Statistical analysis was carried out using the GraphPad Prism 5 program (version 3.02 for Windows; GraphPad Software, CA, USA). Experiments were repeated three times in duplicate for experiments. One-way ANOVA along with Dunnett's test as a follow-up test to ANOVA was performed as appropriate to determine the statistical significance. The statistical significance was established at $\mathrm{P} \leq 0.05$, $\mathrm{P} \leq 0.01, \mathrm{P} \leq 0.001$.

\section{RESULTS AND DISCUSSION}

\section{Effects of pomegranate extract on cell viability}

In this in vitro study, we observed a significant $(\mathrm{P} \leq 0.001)$ increase of viable HGL5 cells after treatment of pomegranate extract at the concentrations 5; 10 and $20 \mu \mathrm{g} / \mathrm{ml}$. Moreover, our results indicated significantly $(\mathrm{P} \leq 0.05 ; \mathrm{P} \leq 0.01$; $\mathrm{P} \leq 0.001$ ) inhibited the proliferation of OVCAR-3 cells in a dose-dependent manner after pomegranate extract application at the concentrations 10;20 and 40 $\mu \mathrm{g} / \mathrm{ml}$. The results are shown in the figure 1 .

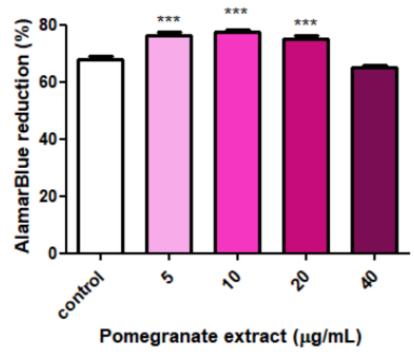

$\mathbf{A}$

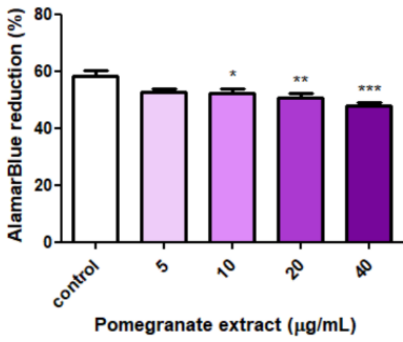

B
Figure 1 The viability of human ovarian granulosa cell line (A) and human ovarian carcinoma cell line (B) without (control) or with pomegranate extract treatment $(5,10,20$ and $40 \mu \mathrm{g} / \mathrm{mL})$ for $24 \mathrm{~h}$. The significance of differences between the groups was evaluated by One-way ANOVA followed by Dunnett's multiple comparison test. The data are expressed as means \pm SEM. AlamarBlue.

\section{Effects of pomegranate extract on the release of steroid hormones}

The current study suggests that pomegranate extract could have an impact on the secretion of steroid hormones $-17 \beta$-estradiol and progesterone by the cells. The results showed a significant $(\mathrm{P} \leq 0.05 ; \mathrm{P} \leq 0.001)$ increase of the $17 \AA$-estradiol secretion by pomegranate extract treatment at the concentrations $5 ; 10 ; 20$ and 40 $\mu \mathrm{g} / \mathrm{ml}$ in comparison to control. On the other hand, progesterone levels were not significantly $(\mathrm{P} \geq 0.05)$ affected at all used concentrations in comparison to control after addition of pomegranate extract. The results are shown in the figure 2 .

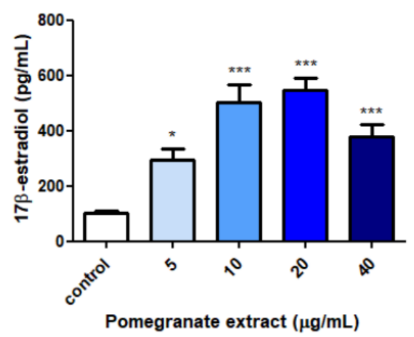

A

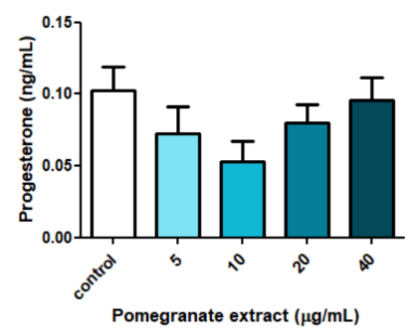

B
Figure 2 The release of 17ß-estradiol (A) and progesterone (B) by HGL5 cells after treatment with pomegranate extract $(5,10,20$ and $40 \mu \mathrm{g} / \mathrm{mL})$ for $24 \mathrm{~h}$. Control represents culture medium without pomegranate extract. The significance of differences between the groups was evaluated by One-way ANOVA followed by Dunnett's multiple comparison test. The data are expressed as means \pm SEM. ELISA.

Nowadays, natural biomolecules and their impact on reproductive functions have attracted a huge scientific attention (Kolesarova et al., 2011; Halenar et al., 2016; Packova et al., 2016; Roychoudhury et al., 2018). Naturally-occurring phytocompounds from dietary fruits and vegetables have received public interest for the prevention and treatment of various diseases (Modaeinama et al., 2015; Sharma et al., 2017).

The quest for effective and safe chemotherapeutic agents is urgently necessary for a view of the fact that many anticancer drugs elicit harmful side effects on normal cells. The current experiments were designed to determine the biological effects of rich-polyphenol pomegranate extract on the viability of human ovarian cells. The stimulation of proliferation of healthy human granulosa cells HGL5 by the pomegranate extract in vitro was observed.

The beneficial properties associated with punicalagin as a major phytocompound of pomegranate, described Packova et al. (2016). In previous study, the proproliferative effect of punicalagin on porcine ovarian granulosa cells in vitro was examined. Further studies of the potential roles of pomegranate in proliferation are therefore needed.

Many reports have shown that the pomegranate as well as juice, extract or oil exert antiproliferative, anti-inflammatory, and anti-cancer properties by modulating multiple signalling pathways (Sharma et al., 2017). In current studies, antioxidants have been examined due to their protective properties against free radical-induced damage. Clinical and experimental studies proved the relationship between a polyphenol-rich diet and reduced risk of degenerative diseases (Vauzour et al., 2010; Viuda-Martos et al., 2010).

Ovarian cancer is one of the most common malignancies in the female reproductive system with high mortality rates worldwide (Liu et al., 2017). In this study, the cell-specific and dose-dependent antiproliferative effect of pomegranate extract as a promising chemo-preventive agent was examined. The polyphenol-rich pomegranate extract inhibited the proliferation of human ovarian 
carcinoma cells OVCAR-3. In accordance with findings the present study, the results conclusively demonstrated the association between dietary flavonoids intake and ovarian cancer risk (McCann et al., 2003; Chang et al., 2007).

Pomegranate polyphenols are potent antioxidants which have been shown both in vitro and in vivo to inhibit the growth of several forms of cancer (Toi et al., 2003; Elfalleh et al., 2011; Modaeinama et al., 2015). Many investigations have established tremendous potential of pomegranate as an anticancer agent against various cancer cells including breast (Kim et al., 2002; Adams et al., 2010), lung (Khan et al., 2007), colon (Larrosa et al., 2006), skin (Hora et al., 2003) prostate (Hong et al., 2008; Seidi et al., 2016) and others. Numerous studies have reported, that pomegranate extracts may affect proliferation by downregulating Akt/mTOR pathways and may induce apoptosis of cancer cells by increasing the Bax/Bcl-2 ratio (Syed et al., 2013; Sharma et al., 2017).

Recently, punicalagin and ellagic acid, present in pomegranate, was described as a possible effector of the cell cycle and have a proapoptotic effect (Gil $\boldsymbol{e t}$ al., 2000). The potent antioxidant pronounced antiproliferative and apoptosisinducing effect of punicalagin in prostate cancer cells in vitro was observed (Adaramoye et al., 2017)

In vitro human cell line models are available for a variety of malignancies, serving as suitable platforms for exploring antiproliferative and cytotoxic effects of natural products. Direct cytotoxic effects might be apoptosis or necrosis (or both) mediated, with a number of mechanisms leading to cell death, changes in proliferation patterns and effects on cell differentiation (Choi et al., 2006) Human ovarian granulosa cells HGL5 maintain key steroidogenic pathways, making them an attractive model to study mechanisms of steroid biosynthesis (Patel et al., 2009). Therefore, we monitor also secretion of steroid hormones by the cells after pomegranate extract treatment. Interestingly, the supplementation by pomegranate extract at selected concentrations increased the secretion of $17 \beta$ estradiol by HGL5 cells but did not significantly affected progesterone levels. In according to previous studies (Papoutsi et al., 2005; Tran et al. 2010), our data suggest that pomegranate is an excellent source of phytoestrogens.

The focus of major research and clinical attention is concentrated on phytoestrogens due to its effectiveness in the prevention and treatment of menopausal symptoms, osteoporosis, cancer and other diseases (Liu et al., 2001, Choi et al., 2006). In contrast to the use of synthetic estrogens, the functional foods containing elevated amounts of phytoestrogens have been recommended for the prevention of breast cancer. One such food is pomegranate fruits that contain phytocompounds with hormone-like activity (Kim et al., 2002).

The main polyphenolic compounds present in the pomegranate fruits of are ellagitannins, such as punicalagin ( $\alpha$ and $\beta$ ), and flavonoids, such as anthocyanidins, catechins, and flavonols (Gonzalez-Trujano et al., 2015) and possess estrogenic activity on in vitro assays (Larossa $\boldsymbol{e t}$ al., 2006; Landete $\boldsymbol{e}$ al., 2011). Papoutsi et al. (2005) investigated the ability of ellagic acid to influence the activity of the estrogen receptor subtypes ER $\alpha$ and ER $\beta$ in HeLa cells.

The effect of the most abundant ellagitannin in pomegranate - punicalagin, on steroidogenesis was examined and the results showed that punicalagin may affect the secretion of 17ß-estradiol as the final product of the pathway (Packova et al., 2015). However, the synergistic action of the pomegranate biosubstances appears to be superior when in comparison to individual components (Viladomiu $\boldsymbol{e t}$ al., 2013)

Similarly, Ming et al. (2014) reported the impact of pomegranate extract on steroidogenesis in prostate cancer cell line and prostate cancer mouse model and suggested that androgen biosynthesis might favour the backdoor pathway over the classical $\Delta 4$ and $\Delta 5$ pathways.

Finally, phytocompounds with phytoestrogenic activity from pomegranate extract could have a potential role as the possible effector in the process of steroidogenesis. The results from previous studies support the fact that pomegranate is indeed a unique fruit and potent source of biologically active phytochemicals with beneficial properties.

\section{CONCLUSION}

In conclusion, the pomegranate extracts may be used as a source of health promoting phytocompounds for developing new functional foods. The beneficial effect of pomegranate extract on the viability of HGL5 cells and antiproliferative effect on the cancer cells OVCAR-3 was studied and quantified. Thus, it can be indicated that pomegranate fruit may contain the bioactive compounds which possess both antiproliferative effect and cell proliferative stimulator in celldependent manner. Additionally, rich-polyphenol pomegranate extract may be a potential endocrine modulator of steroidogenesis in ovarian cells. However, further research is essential to understanding the therapeutic potential of pomegranate and its mechanisms of action.

Acknowledgements: This work was supported by the Ministry of Education, Science, Research and Sport of the Slovak Republic projects VEGA 1/0039/16, APVV- 15-0543, APVV-16-0289, The Excellent scientific team "Center of Animal Reproduction (CeRA)", Tatra bank Foundation 2018, and European Community under project number 26220220180 for Building Research Centre "AgroBioTech".

\section{REFERENCES}

ADAMS, L. S., ZHANG, Y., SEERAM, N. P., HEBER, D., CHEN, S. 2010. Pomegranate ellagitannin-derived compounds exhibit antiproliferative and antiaromatase activity in breast cancer cells in vitro. Cancer Prevention Research, 3(1), 108-113. https://doi.org/10.1158/1940-6207.capr-08-0225

ADARAMOYE, O., EFQUEN, B., NITZSCHE, B., HÖPFNER, M., JUNG, K., RABIEN, A. 2017. Punicalagin, a polyphenol from pomegranate fruit, induces growth inhibition and apoptosis in human PC-3 and LNCaP cells. ChemicoBiological Interaction, 274, 100-106. https://doi.org/10.1016/j.cbi.2017.07.009 AKHTAR, S., ISMAIL, T., FRATERNALE, D., SESTILI, P. 2015. Pomegranate peel and peel extracts: Chemistry and food features. Food Chemistry, 174, $417-$ 425. https://doi.org/10.1016/j.foodchem.2014.11.035

AL-MUAMMAR, M. N., KHAN, F. 2012. Obesity: The preventive role of the pomegranate (Punica granatum). Nutrition, 28, 595-604. https://doi.org/10.1016/j.nut.2011.11.013

AL-SAID, F. A., OPARA, L. U., AL-YAHYAI, R. A. 2009. Physico-chemical and textural quality attributes of pomegranate cultivars (Punica granatum L.) grown in the Sultanate of Oman. Journal of Food Engineering, 90(1), 129-134 https://doi.org/10.1016/j.jfoodeng.2008.06.012

AQIL, F., MUNAGALA, R., VADHANAM, M. V., KAUSAR, H., JEYABALAN, J., SCHULTZ, D. J., GUPTA, R. C. 2012. Anti-proliferative activity and protection against oxidative DNA damage by punicalagin isolated from pomegranate husk. Food Research International, 49(1), 345-353. https://doi.org/10.1016/j.foodres.2012.07.059

BANNERMAN, D. D., TUPPER, J. C., RICKETTS, W. A., BENNETT, C. F. WINN, R. K., HARLAN, J. M. 2001. A constitutive cytoprotective pathway protects endothelial cells from lipopolysaccharide-induced apoptosis. Journal of Biological Chemistry, $276 \quad$ (18), $\quad 14924-14932$ https://doi.org/10.1074/jbc.m100819200

CHANG, E. T., LEE, V. S., CANCHOLA, A. J., CLARKE, C. A., PURDIE, D. M., REYNOLDS, P., ANTON-CULVER, H., BERNSTEIN, L., DEAPEN, D., et al. 2007. Diet and risk of ovarian cancer in the California Teachers Study cohort. American Journal of Epidemiology, 165(7), 802-813.

https://doi.org/10.1093/aje/kwf224

CHOI, D. W., KIM, J. Y., CHOI, S. H., JUNG, H. S., KIM, H. J., CHO, S. Y. KANG, C. S., CHANG, S. Y. 2006. Identification of steroid hormones in pomegranate (Punica granatum) using HPLC and GC-mass spectrometry. Food Chemistry, 96(4), 562-571. https://doi.org/10.1016/j.foodchem.2005.03.010

CHOI, Y. J., PARK, J. H., HAN, J. W., KIM, E., JAE-WOOK, O., LEE, S. Y GURUNATHAN, S. 2016. Differential cytotoxic potential of silver nanoparticles in human ovarian cancer cells and ovarian cancer stem cells. International Journal of Molecular Sciences, 17(12), 2077. https://doi.org/10.3390/ijms17122077

ELFALLEH, W., TLILI, N., NASRI, N., YAHIA, Y., HANNACHI, H. CHAIRA, M. Z., FERCHICHI, A. 2011. Antioxidant capacities of phenolic compounds and tocopherols from Tunisian pomegranate (Punica granatum) fruits. Journal of Food Science, 76(5), C707-C713 https://doi.org/10.1111/j.1750-3841.2011.02179.x

GIL, M. I., TOMÁS-BARBERÁN, F. A., HESS-PIERCE, B., HOLCROFT, D. M., KADER, A. A. 2000. Antioxidant activity of pomegranate juice and its relationship with phenolic composition and processing. Journal of Agricultural Food Chemistry, 48(10), 4581-4589. https://doi.org/10.1021/jf000404a GONZALEZ-TRUJANO, M. E., PELLICER, F., MENA, P., MORENO, D. A., GARCÍA-VIGUERA, C. 2015. Antinociceptive and anti-inflammatory activities of a pomegranate (Punica granatum L.) extract rich in ellagitannins. International Journal of Food Sciences and Nutrition, 66(4), 395399. https://doi.org/10.3109/09637486.2015.1024208

HALENAR, M., KOVACIKOVA, E., NYNCA, A., SADOWSKA, A. 2016 Stimulatory effect of amygdalin on the viability and steroid hormone secretion by porcine ovarian granulosa cells in vitro. Journal of Microbiology and Biotechnology and Food Science, 5 (Special 1), 44-46. https://doi.org/10.15414/jmbfs.2016.5.special1.44-46

HAMILTON, T. C., YOUNG, R. C., McKOY, W. M., GROTZINGER, K. R. GREEN, J. A., CHU, E. W., WHANG-PENG, J., ROGAN, A. M., GREEN, W. R., OZOLS, R. F. et al. 1983. Characterization of a human ovarian carcinoma cell line (NIH: OVCAR-3) with androgen and estrogen receptors. Cancer Research, 43(11), 5379-5389. ISSN 0008-5472.

HAVELOCK, J. C., RAINEY, W. E., CARR, B. R. 2004. Ovarian granulosa cell lines. Molecular and Cellular Endocrinology, 228(1-2), 67-78 https://doi.org/10.1016/j.mce.2004.04.018

HONG, M. Y., SEERAM, N. P., HEBER, D. 2008. Pomegranate polyphenols down-regulate expression of androgen-synthesizing genes in human prostate cancer cells overexpressing the androgen receptor. Journal of Nutritional Biochemistry, 19(12), 848-855. https://doi.org/10.1016/j.jnutbio.2007.11.006

HORA, J. J., MAYDEW, E. R., LANSKY, E. P., DWIVEDI, C. 2003. Chemopreventive effects of pomegranate seed oil on skin tumor development in CD1 mice. Journal of Medicinal Food, 6(3), 157 161. https://doi.org/10.1089/10966200360716553 
KIM, N. D., MEHTA, R., YU, W., NEEMAN, I., LIVNEY, T., AMICHAY, A., POIRIER, D., NICHOLLS, P., KIRBY, A., et al. 2002. Chemopreventive and adjuvant therapeutic potential of pomegranate (Punica granatum) for human breast cancer. Breast Cancer Research and Treatment, 71(3), 203-217. https://doi.org/10.1023/A:1014405730585

KHAN, N., HADI, N., AFAQ, F., Syed, D. N., KWEON, M. H., MUKHTAR, H. 2007. Pomegranate fruit extract inhibits prosurvival pathways in human A549 lung carcinoma cells and tumor growth in athymic nude mice. Carcinogenesis, 28(1), 163-173. https://doi.org/10.1093/carcin/bgl145

KOLESAROVA, A., CAPCAROVA, M., BAKOVA, Z., GALIK, B., JURACEK, M., SIMKO, M., SIROTKIN, A. V. 2011. The effect of bee pollen on secretion activity, markers of proliferation and apoptosis of porcine ovarian granulosa cells in vitro. Journal of Environmental Science and Health Part B, 46(3), 207-212. https://doi.org/10.1080/03601234.2011.540202

KOLESÁROVÁ, A., SIROTKIN, A. V., MELLEN, M., ROYCHOUDHURY, S. 2015. Possible intracellular regulators of female sexual maturation. Physiological research, 64, 379-386. ISSN 0862-8408

LANDETE, J. M. 2011. Ellagitannins, ellagic acid and their derived metabolites: a review about source, metabolism, function and health. Food Research International, 44, 1150-1160. https://doi.org/10.1016/j.foodres.2011.04.027

LARROSA, M., TOMÁS-BARBERÁN, F. A., ESPÍN, J. C. 2006. The dietary hydrolysable tannin punicalagin releases ellagic acid that induces apoptosis in human colon adenocarcinoma Caco-2 cells by using the mitochondrial pathway. Journal of Nutritional Biochemistry, 17(9), 611-625. https://doi.org/10.1016/j.jnutbio.2005.09.004

LIU, H., YUE, Q., HE, S. 2017. Amentoflavone suppresses tumor growth in ovarian cancer by modulating Skp2. Life Sciences, 189, 96-105. https://doi.org/10.1016/j.lfs.2017.09.026

McCANN, S. E, FREUDENHEIM, J. L., MARSHALL, J. R., GRAHAM, S 2003. Risk of human ovarian cancer is related to dietary intake of selected nutrients, phytochemicals and food groups. Journal of Nutrition, 133(6), 19371942. https://doi.org/10.1093/jn/133.6.1937

MING, D. S., PHAM, S., DEB, S., CHIN, M. Y., KHARMATE, G., ADOMAT, H., BEHESHTI, E. H., LOCKE, J., GUNS, E. T. 2014. Pomegranate extracts impact the androgen biosynthesis pathways in prostate cancer models in vitro and in vivo. Journal of Steroid Biochemistry and Molecular Biology, 143, 19-28. https://doi.org/10.1016/j.jsbmb.2014.02.006

MODAEINAMA, S., ABASI, M., ABBASI, M. M., JAHANBAN-ESFAHLAN, R. 2015. Anti-tumoral properties of Punica granatum (Pomegranate) peel extract on different human cancer cells. Asian Pacific Journal of Cancer Prevention, 16(14), 5697-5701. https://doi.org/10.1016/j.foodres.2012.07.059 MOUSAVINEJAD, G., EMAM-DJOMEH, Z. - REZAEI, K. KHODAPARAST, M. H. H. 2009. Identification and quantification of phenolic compounds and their effect on antioxidant activity in pomegranate juices of eight Iranian cultivars. Food Chemistry, 115(4), 1274-1278. https://doi.org/10.1016/j.foodchem.2009.01.044

PACKOVA, D., CARBONELL-BARRACHINA, A. A., KOLESAROVA, A 2015. Ellagitannins - compounds from pomegranate as possible effector in steroidogenesis of rabbit ovaries. Physiological Research 2 64, 583-585. ISSN 0862-8408

PACKOVA, D., KOLESAROVA, A. 2016. Do punicalagins have possible impact on secretion of steroid hormones by porcine ovarian granulosa cells? Journal of Microbiology, Biotechnology and Food Sciences, 5, 57-59. https://doi.org/10.15414/jmbfs.2016.5.special1.57-59

PAPOUTSI, Z., KASSI, E., TSIAPARA, A., FOKIALAKIS, N., CHROUSOS, G. P., MOUTSATSOU, P. 2005. Evaluation of estrogenic/antiestrogenic activity of ellagic acid via the estrogen receptor subtypes ER $\alpha$ and ER $\beta$. Journal of Agricultural and Food Chemistry, 53(20), 7715-7720. https://doi.org/10.1021/jf0510539

PATEL, S. S., BESHAY, V. E., ESCOBAR, J. C., SUZUKI, T, CARR, B. R. 2009. Molecular mechanism for repression of 17alpha-hydroxylase expression and androstenedione production in granulosa cells. Journal of Clinical Endocrinology and $\quad$ Metabolism, 94(12), 5163-5168. https://doi.org/10.1210/jc.2009-1341

RAINEY, W. H., SAWETAWAN, C., SHAY, J. W. MICHAEL, M. D., MATHIS, J. M., KUTTEH, W., BYRD, W., CARR, B. R. 1994. Transformation of human granulosa cells with the E6 and E7 regions of human papillomavirus. Journal of Clinical Endocrinology and Metabolism, 78(3), 705-710. https://doi.org/10.1210/jcem.78.3.8126145

ROYCHOUDHURY, S., HALENAR, M., MICHALCOVA, K., NATH, S., KACANIOVA, M., KOLESAROVA, A. 2018. Green tea extract affects porcine ovarian cell apoptosis. Reproductive Biology, 18(1), 94-98. https://doi.org/10.1016/j.repbio.2018.01.007

SCHAMS, D., BERISHA, B. 2002. Steroids as local regulators of ovarian activity in domestic animals. Domestic Animal Endocrinology, 23(1-2), 53-65. https://doi.org/10.1016/S0739-7240(02)00145-5

SEERAM, N. P., ADAMS, L. S., HENNING, S. M., NIU, Y., ZHANG, Y., NAIR, M. G., HEBER, D. 2005. In vitro anti-proliferative, apoptotic and antioxidant activities of punicalagin, ellagic acid and a total pomegranate tannin extract are enhanced in combination with other polyphenols as found in pomegranate juice. Journal of Nutritional Biochemistry, 16(6), 360367.https://doi.org/10.1016/j.jnutbio.2005.01.006

SEIDI, K., JAHANBAN-ESFAHLAN, R., ABASI, M., ABBASI, M. M. 2016. Anti-tumoral properties of Punica granatum (Pomegranate) Seed extract in different human cancer cells. Asian Pacific Journal of Cancer Prevention, 17(3), 1119-1122. https://doi.org/10.7314/APJCP.2015.16.14.5697

SHARMA, P., SARAH, F. C., AFAQ, F. 2017. Pomegranate for prevention and treatment of cancer: An update. Molecules, 22(1), 177 https://doi.org/10.3390/molecules22010177

SINGH, M., JHA, A., KUMAR, A., HETTIARACHCHY, N., RAI, A. K. 2014 Influence of the solvents on the extraction of major phenolic compounds (punicalagin, ellagic acid and gallic acid) and their antioxidant activities in pomegranate aril. Journal of Food Science and Technology, 51(9), 2070-2077. https://doi.org/10.1007/s13197-014-1267-0

SYED, N. D., CHAMCHEU, J. C., ADHAMI, V. M., MUKHTAR, H. 2013. Pomegranate extracts and cancer prevention: Molecular and cellular activities. Anti-cancer Agents in Medicinal Chemistry, 13(8), 11491161. https://doi.org/10.2174/1871520611313080003

TOI, M., BANDO, H., RAMACHANDRAN, C., MELNICK, S. J., IMAI, A., FIFE, R. S., CARR, R. E., OIKAWA, T., LANSKY, E. P. 2003. Preliminary studies on the anti-angiogenic potential of pomegranate fractions in vitro and in vivo. Angiogenesis, 6(2), 121-128. https://doi.org/10.1089/10966200360716553 TRAN, H. N., BAE, S. Y., SONG, B. H., LEE, B. H., BAE, Y. S, KIM, Y. H. 2010. Pomegranate (Punica granatum) seed linolenic acid isomers: concentration-dependent modulation of estrogen receptor activity. Endocrine Research, 35(1), 1-16. https://doi.org/10.3109/07435800903524161

VAUZOUR, D., RODRIGUEZ-MATEOS, A., CORONA, G., ORUNACONCHA, M. J., SPENCER, J. P. E. 2010. Polyphenols and human health: Prevention of disease and mechanisms of action. Nutrients, 2(11), 1106-1131 https://doi.org/1106-1131.10.3390/nu2111106

VILADOMIU, M., HONTECILLAS, R., LU, P., BASSAGANYA-RIERA, J. 2013. Preventive and prophylactic mechanisms of action of pomegranate bioactive constituents. Evidence-based complementary and alternative medicine. 2013,789764. http://doi.org/10.1155/2013/789764

VIUDA-MARTOS, M., FERNANDEZ-LOPEZ, J., PEREZ-ALVAREZ, J. A. 2010. Pomegranate and its Many Functional Components as Related to Human Health: A Review. Comprehensive Reviews in Food Science and Food Safety, 9(6), 635-654. https://doi.org/10.1111/j.1541-4337.2010.00131.x

YUAN, T., MA, H., LIU, W., NIESEN, D. B., SHAH, N., CREWS, R., ROSE, K. N., VATTEM, D. A, SEERAM, N. P. 2016. Pomegranate's Neuroprotective Effects against Alzheimer's Disease Are Mediated by Urolithins, Its EllagitanninGut Microbial Derived Metabolites. ACS Chemical Neuroscience, 7(1), 26-33. https://doi.org/10.1021/acschemneuro.5b00260

ZHANG, L., FU, Q., ZHANG, Y. 2011. Composition of anthocyanins in pomegranate flowers and their antioxidant activity. Food Chemistry, 127(4), 1444-1449. https://doi.org/10.1016/j.foodchem.2011.01.077 